Research Article

\title{
Blood Urea Nitrogen, Serum Creatinine and Blood Urea Nitrogen to Creatinine Ratio Reference Values in Iranian Children
}

\author{
Mahtab Rahbar*1(D), Keykhosro Mardanpour $^{2}$ (D), Nyousha $\operatorname{Mardanpour}^{1}{ }^{\text {(iD }}$ \\ 1. Iran University of Medical Sciences, Tehran, Iran \\ 2. Kermanshah University of Medical Sciences, Kermanshah, Iran \\ *Correspondence: Mahtab Rahbar, Iran University of Medical Sciences, Hemmat Boulevard, \\ Tehran, Iran \\ Tel: +989125214011 \\ Email: rahbar.m@iums.ac.ir
}

\begin{tabular}{l} 
Received February 06, $2021 \quad$ Accepted February 20, 2021 \\
\hline ABSTRACT \\
Background and objectives: Reference values of blood urea nitrogen (BUN), serum creatinine \\
(sCr) and BUN to creatinine ratio (BCR) in the different pediatric populations are not well- \\
established yet. The aim of this study was to determine reference values of BUN, sC and BCR in \\
healthy Iranian children.
\end{tabular}
hospitalized at Ali-Asghar Children's Hospital (Tehran, Iran) between April 2016 and May 2018. The subjects were stratified into three age groups: toddlers, developing children and adolescents. Demographic data, medical history and laboratory findings were extracted from medical records of the subjects. Statiscal analyses were peformed using SPSS at statistical significance of 0.05.

Results: The mean (95th Percentile) level of BUN was $12.60 \mathrm{mg} / \mathrm{dl}$ (range: 6.8 to $20.5 \mathrm{mg} / \mathrm{dl}$ ). The mean and 95th percentile of $\mathrm{sCr}$ was $0.77 \mathrm{mg} / \mathrm{dl}$ (range: 0.8 to $1.15 \mathrm{mg} / \mathrm{dl}$ ). The mean and 95th percentile of BCR was 16 (range: 12.75 to 15.4). The BUN, sCr and BCR levels differed significantly between males and females $(\mathrm{P}<0.05)$. In both genders, the concentrations of BUN and $\mathrm{sCr}$ were significantly higher in older children $(\mathrm{P}<0.05)$. On the contrary, the $\mathrm{BCR}$ value decreased significantly with age in both males and females $(\mathrm{P}<0.05)$.

Conclusion: This study is the first to report the BUN, sCr, and BCR reference values among healthy Iranian children. These values can be used by clinicians for diagnostic and therapeutic purposes.

Keywords: Blood urea nitrogen; creatinine; children; Iran

DOI: 10.29252/Jcbr.5.1.14

(c) (1) (8)

This work is licensed under a Creative Commons Attribution 4.0 License.

(C) The authors 


\section{INTRODUCTION}

Blood urea nitrogen (BUN) is a clinical test to measure the amount of urea nitrogen in the blood. Urea is a product of protein metabolism in the liver. In fact, BUN is a non-protein nitrogenous (NPN) waste product of amino acids that is converted to urea by liver enzymes and later excreted by the renal system. However, the concentration of urea is dependent on protein intake $(\underline{1}, 2)$. BUN is an indicator of renal function and ranges between 2.1 and $7.1 \mathrm{mmol} / \mathrm{L}$ or 6 and $20 \mathrm{mg} / \mathrm{dL}$ in adults. However, the reference ranges may differ between laboratories depending on the assay methods. BUN is influenced by various factors such as protein diet, variables in protein synthesis, the patient's hydration status and renal function status. The level of BUN is not a suitable marker for renal clearance (3). Frequently, BUN is measured using the uricase and glutamate dehydrogenase methods that both measure ammonium (4).

Creatine is generally synthesized in the liver, pancreas, and kidneys. The produced creatine in then phosphorylated and converted to phosphocreatine in the skeletal muscle and brain. About $2 \%$ of creatine is converted to creatinine every day. Creatinine is a NPN byproduct of creatine breakdown (5). The kidneys filter out most of the creatinine in urine. Elevated creatinine levels could suggest kidney dysfunction. Some temporary factors may cause a slightly higher serum creatinine ( $\mathrm{sCr}$ ) and BUN level. Persistently high level of $\mathrm{sCr}$ and BUN can result in severe kidney damage (ㅁ). The sCr test be performed either chemically or enzymatically. The Jaffe reaction is a chemical method that is nonspecific for measuring creatinine because it can be influenced by the presence of ascorbic acid, acetone and cephalosporins erroring the samples. Moreover, the chemical method is time-consuming and not commonly used in automated analyzers ( $\underline{5})$. In addition, $\mathrm{sCr}$ can be measured enzymatically by assessing the activity of creatininase. It is well-demonstrated that the $\mathrm{BUN} /$ plasma creatinine ratio (BCR) provides a more accurate estimation of kidney function $(\underline{6}, \underline{7})$. Given the importance of determining reference values of BUN and $\mathrm{sCr}$ in different countries, we conducted this study using a comprehensive database to introduce $\mathrm{BUN}, \mathrm{sCr}$ and $\mathrm{BCR}$ reference values in Iranian children.

\section{MATERIALS AND METHODS}

This retrospective study was conducted on 3268 children who were hospitalized at AliAsghar Children's Hospital affiliated to Iran University of medical science (Tehran, Iran) between April 2016 and May 2018. The subjects were divided into three age groups: toddlers, developing children and adolescents. Those without a history of kidney or urinary tract diseases or candidates for tonsillectomy, circumcise, herniotomy and hirschsprung disease were considered as healthy children. A history of chronic diseases such as diabetic mellitus, hepatic diseases and renal diseases as well as consumption of medications known to affect the liver or kidneys were considered as the exclusion criteria. A well-designed questionnaire was prepared to collected demographic data, medical history, cause of admission and clinical laboratory findings such as BUN and sCr.

According to the hospital protocols for BUN and $\mathrm{sCr}$ testing, non-fasting blood samples $(5 \mathrm{ml})$ were taken in the morning in a sitting position. Measurement of BUN and $\mathrm{sCr}$ were carried out using the Cobas Integra ${ }^{\circledR} 400$ plus automated analyzer (Roche Diagnostics, Mannheim, Germany). Calibrator for automated systems (C.f.a.s) was used. Quality assurance/quality control was done to ensure the accuracy and precision of the test results. Quality control was performed as defined in the test specification for every analysis $(\underline{8}-\underline{11})$. The BCR value was calculated manually. The 
study was approved by the Ethics Committee of the hospital. All personal information remained confidential throughout the study.

For data analysis, the mean and 95th percentile average of $\mathrm{BUN}, \mathrm{sCr}$ and $\mathrm{BCR}$ were used. The Pearson's correlation coefficient was used to evaluate correlations between the parameters. Comparison of BUN, sCr and BCR values between males and females was carried out using the Mann-Whitney $U$ test. All statistical analyses were performed using SPSS 16.0 statistical software package (SPSS, Chicago, IL, USA) or Graph Pad Prism (Graph Pad
Software Inc., San Diego, CA) at significance of 0.05 .

\section{RESULTS}

A total number of 3268 children were included in the study. There were 1670 $(51.1 \%)$ males and $1598(48.9 \%)$ females. The mean \pm standard deviation $(\mathrm{SD})$ of BUN reference value was $12.60 \pm 2.20 \mathrm{mg} / \mathrm{dl}$. This value was $13.08 \pm 2.10 \mathrm{mg} / \mathrm{dl}$ for males and $12.11 \pm 2.31 \mathrm{mg} / \mathrm{dl}$ for females. The ninety-fifth percentile for BUN was 6.8 to $20.5 \mathrm{mg} / \mathrm{dl}$ for the study population (Table 1).

Table 1. Reference value of BUN (mg/dl) according to age and gender

\begin{tabular}{|c|c|c|c|c|c|c|c|}
\hline Gender & Age (years) & Numbers & $\begin{array}{c}95 \% \\
\text { Reference } \\
\text { intervals }\end{array}$ & $\begin{array}{l}\text { Max value } \\
\text { (mg/dl) }\end{array}$ & $\begin{array}{c}\text { Min value } \\
(\mathrm{mg} / \mathrm{dl})\end{array}$ & $\begin{array}{l}\text { Median } \\
\text { (mg/dl) }\end{array}$ & $\begin{array}{c}\text { Mean } \pm \text { SD } \\
(\mathrm{mg} / \mathrm{dl})\end{array}$ \\
\hline \multirow{4}{*}{ Male } & $1-5$ & 625 & $0.60-1.10$ & 22 & 7.5 & 14.75 & \multirow{4}{*}{$13.08 \pm 2.10$} \\
\hline & $6-10$ & 536 & $0.50-1.00$ & 20 & 7 & 13.5 & \\
\hline & $11-15$ & 509 & $0.50-1.10$ & 19 & 6 & 12.5 & \\
\hline & $1-15$ & 1670 & $0.60-1.20$ & 20.5 & 6.8 & 13.6 & \\
\hline \multirow{4}{*}{ Female } & $1-5$ & 561 & $0.50-1.10$ & 20 & 7 & 13.5 & \multirow{4}{*}{$12.11 \pm 2.31$} \\
\hline & $6-10$ & 486 & $0.50-1.00$ & 19 & 6 & 12.5 & \\
\hline & $11-15$ & 551 & $0.50-1.10$ & 18 & 5 & 11.5 & \\
\hline & $1-15$ & 1598 & $0.60-1.10$ & 19 & 6 & 12.5 & \\
\hline Total & & 3268 & $0.60-1.20$ & 20.5 & 6.8 & 13.65 & $12.60 \pm 2.20$ \\
\hline
\end{tabular}

The mean reference value of $\mathrm{sCr}$ was $0.77 \pm 0.05 \mathrm{mg} / \mathrm{dl}$. This value was $0.83 \pm 0.05 \mathrm{mg} / \mathrm{dl}$ for males and $0.76 \pm 0.05 \mathrm{mg} / \mathrm{dl}$ for females. The ninety-fifth percentile for BUN was 1.15 to $8 \mathrm{mg} / \mathrm{dl}$ for the study population (Table 2).

Table 2. Reference value of $\mathrm{sCr}(\mathrm{mg} / \mathrm{dl})$ according to age and gender

\begin{tabular}{|c|c|c|c|c|c|c|c|}
\hline Gender & Age (years) & Numbers & $\begin{array}{c}95 \% \\
\text { Reference } \\
\text { intervals }\end{array}$ & $\begin{array}{c}\text { Max } \\
\text { value } \\
\text { (mg/dl) }\end{array}$ & $\begin{array}{c}\text { Min } \\
\text { value } \\
\text { (mg/dl) }\end{array}$ & $\begin{array}{c}\text { Median } \\
\text { (mg/dl) }\end{array}$ & $\underset{(\mathrm{mg} / \mathrm{dl})}{\operatorname{Mean} \pm \text { SD }}$ \\
\hline \multirow{4}{*}{ Male } & $1-5$ & 625 & $0.60-1.10$ & 1.1 & 0.5 & 0.8 & \multirow{4}{*}{$0.83 \pm 0.05$} \\
\hline & $6-10$ & 536 & $0.50-1.10$ & 1.2 & 0.6 & 0.9 & \\
\hline & $11-15$ & 509 & $0.50-1.00$ & 1.3 & 0.7 & 1.0 & \\
\hline & $1-15$ & 1670 & $0.60-1.20$ & 1.2 & 0.6 & 0.9 & \\
\hline \multirow{4}{*}{ Female } & $1-5$ & 561 & $0.60-1.10$ & 0.9 & 0.4 & 0.7 & \multirow{4}{*}{$0.76 \pm 0.05$} \\
\hline & $6-10$ & 486 & $0.50-1.00$ & 1.1 & 0.5 & 0.8 & \\
\hline & $11-15$ & 551 & $0.50-1.00$ & 1.2 & 0.6 & 0.9 & \\
\hline & $1-15$ & 1598 & $0.60-1.20$ & 1.0 & 0.5 & 0.8 & \\
\hline Total & & 3268 & $0.60-1.20$ & 1.15 & 0.8 & 1.0 & $0.77 \pm 0.05$ \\
\hline
\end{tabular}

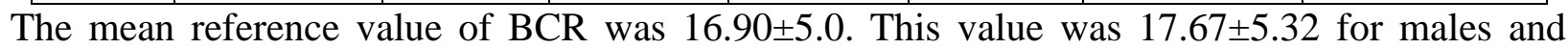
$16.08 \pm 4.66$ for females. The ninety-fifth percentile for BUN was 12.75 to 18 for the study population (Table 3 ). 
Table 3. Reference value of BCR according to age and gender

\begin{tabular}{|c|c|c|c|c|c|c|c|}
\hline Gender & Age (years) & Numbers & $\begin{array}{c}95 \% \\
\text { Reference } \\
\text { intervals }\end{array}$ & $\begin{array}{c}\text { Max } \\
\text { value } \\
\text { (mg/dl) }\end{array}$ & $\begin{array}{c}\text { Min } \\
\text { value } \\
\text { (mg/dl) }\end{array}$ & $\begin{array}{c}\text { Median } \\
(\mathrm{mg} / \mathrm{dl})\end{array}$ & $\begin{array}{c}\text { Mean } \pm \text { SD } \\
(\mathrm{mg} / \mathrm{dl})\end{array}$ \\
\hline \multirow{4}{*}{ Male } & $1-5$ & 625 & $0.60-1.20$ & 24.5 & 19 & 21.75 & \multirow{4}{*}{$17.67 \pm 5.32$} \\
\hline & $6-10$ & 536 & $0.50-1.10$ & 15.5 & 11.5 & 13.5 & \\
\hline & $11-15$ & 509 & $0.50-1.00$ & 14.5 & 8.5 & 11.5 & \\
\hline & $1-15$ & 1670 & $0.60-1.20$ & 18.17 & 13 & 15.6 & \\
\hline \multirow{4}{*}{ Female } & $1-5$ & 561 & $0.60-1.10$ & 22 & 17.5 & 19.75 & \multirow{4}{*}{$16.08 \pm 4.66$} \\
\hline & $6-10$ & 486 & $0.50-1.00$ & 15 & 12 & 13.5 & \\
\hline & $11-15$ & 551 & $0.50-1.10$ & 15 & 8 & 11.5 & \\
\hline & $1-15$ & 1598 & $0.60-1.20$ & 17.4 & 12.5 & 14.9 & \\
\hline Total & & 3268 & $0.50-1.20$ & 18 & 12.75 & 15.4 & $16.90 \pm 5.0$ \\
\hline
\end{tabular}

There BUN, sCr and BCR values differed significantly between males and females (Figures 1-3 $)$. As shown in figure 1 , in both genders, BUN increased significantly with age (males $=\mathrm{P}<0.04$, females $=\mathrm{P}<0.03)$.

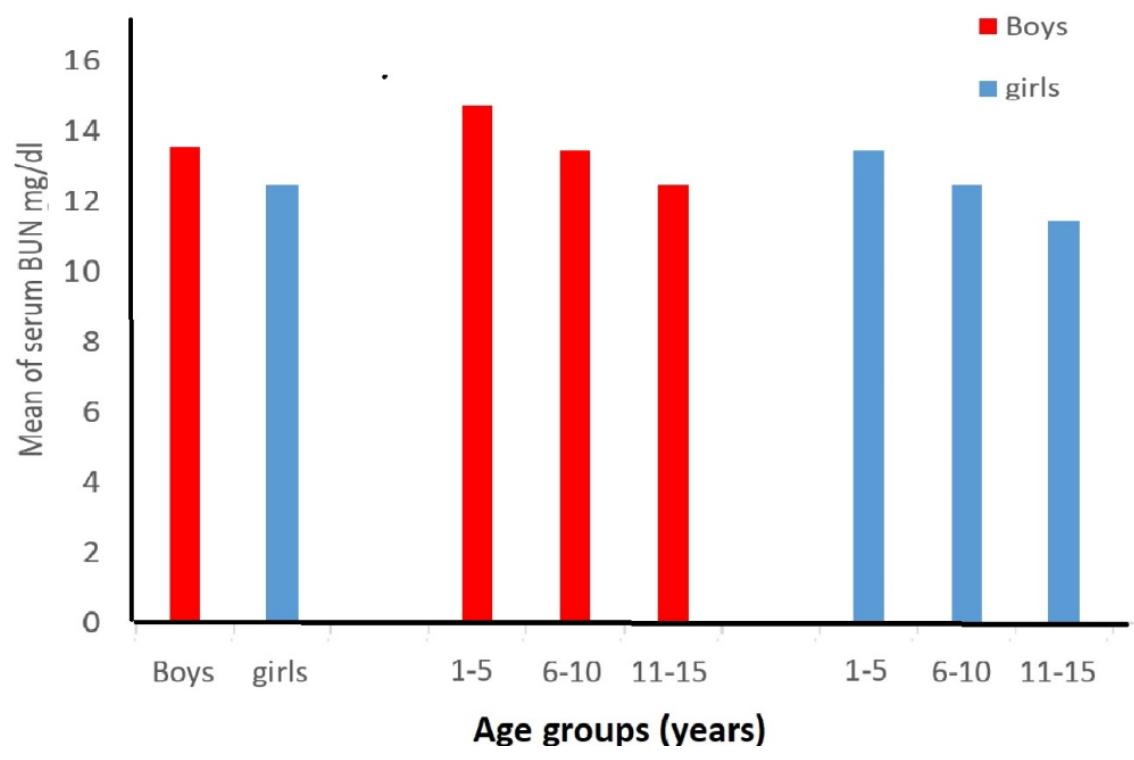

Figure 1. Comparison of BUN values according to age groups and gender.

Based on the results, sCr increased significantly with age in both males $(\mathrm{P}<0.05)$ and females $(\mathrm{P}<0.03)$ (Figure 2). 


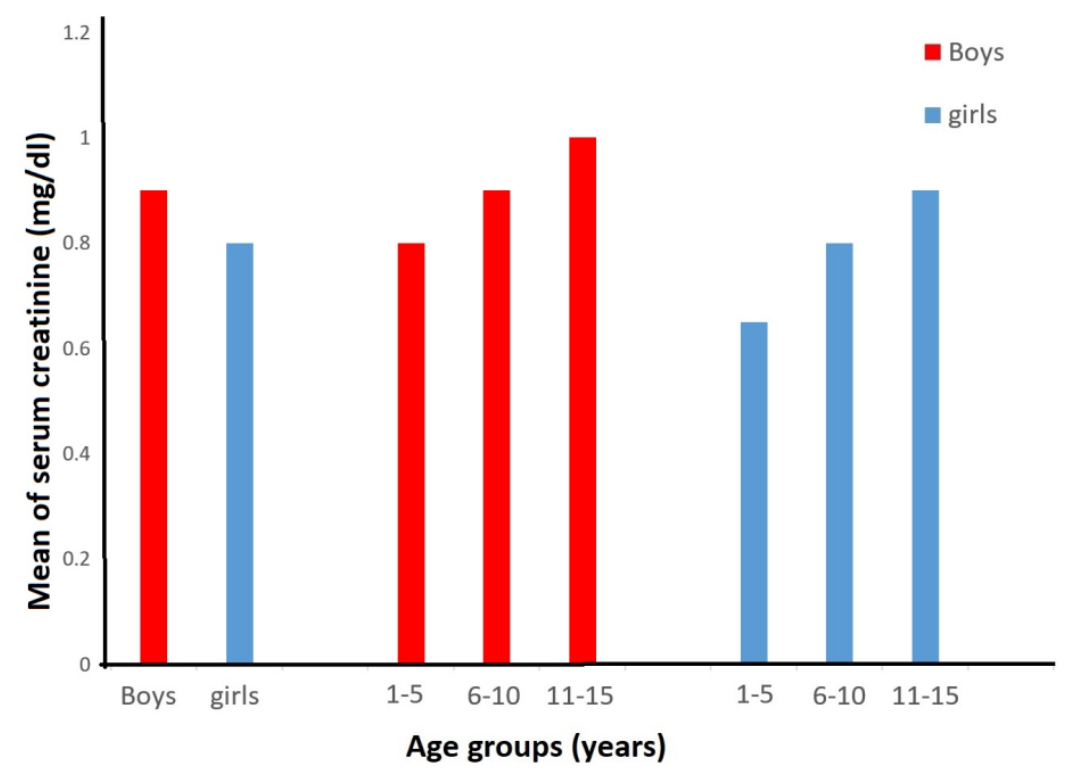

Figure 2. Comparison of $\mathrm{sCr}$ values according to age groups and gender.

Moreover, BUN and $\mathrm{sCr}$ were significantly higher in males than in females $(\mathrm{P}<0.05)$. As shown in figure 3, BCR decreased significantly with age in both males and females $(\mathrm{P}<0.04)$. In fact, there was a significant negative correlation between BCR and age in the study population.

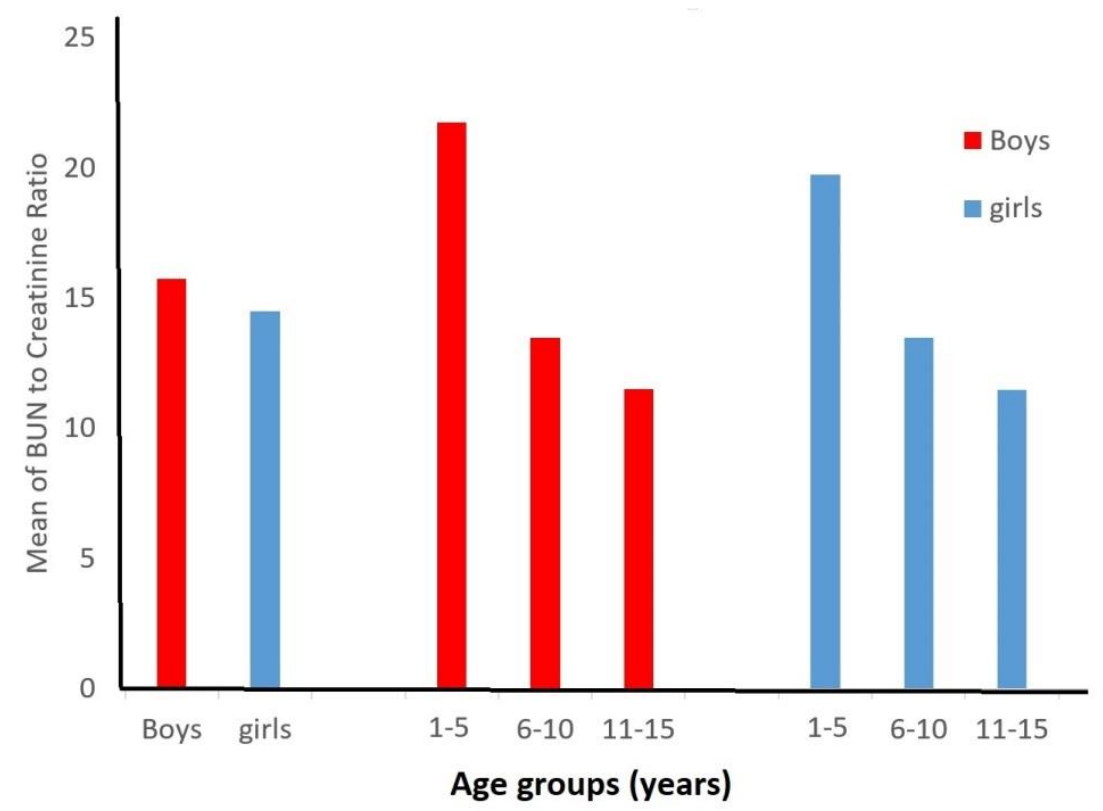

Figure 3. Comparison of BCR values according to age groups and gender. 


\section{DISCUSSION}

Reference values should be established whenever a new test is introduced or an existing method is changed. The National Committee for Clinical Laboratory Standards (NCCLS) recommends testing at least 120 samples for the establishment of a statistically significant reference interval. Other experts recommend a minimum of 200 samples to ensure stable lower and upper reference limits (12). In the present study, pre-analytical factors such as the timing of collection, consumption of food and water and medication 24 hours before testing, venipuncture site, tourniquet time and type of sample collection tube were controlled to ensure that accurate reference values are derived. This study is the first to establish reference values of $\mathrm{BUN}, \mathrm{sCr}$ and BCR for healthy children aged 1-15 years in Iran. Each age group had a minimum of 486 subjects that is required for $95 \%$ reference interval determination as recommended by the NCCLS (12). However, the rate of urea production is elevated in those with a high protein diet and conditions characterized by enhanced tissue breakdown such as massive bleeding, trauma, glucocorticoid therapy and some antibiotic therapies. It is known that a low-protein diet or liver disease can decrease the BUN level without affecting glomerular filtration rate or renal function. Our study showed that the reference value of $\mathrm{sCr}$ concentration was age- and genderdependent among the Iranian children. Our study showed that boys had significantly higher BUN concentrations compared to girls. Another study reported that the value of $\mathrm{sCr}$ is sex-related after the age of 14 years and increases steadily towards the adult levels (13). In our study, the $\mathrm{sCr}$ value in subjects $\geqslant 11$ years was similar to that in the adult population. The $\mathrm{sCr}$ levels were significantly higher in males than in female subjects. It has been well-demonstrated that $\mathrm{sCr}$ values generally increase with age during sexual maturation. The $\mathrm{sCr}$ value can range from 0.5 to $1.0 \mathrm{mg} / \mathrm{dL}$, according to the diurnal and menstrual variations, race, diet and even method of meat preparation $(\underline{14}, \underline{15})$. Furthermore, intense exercise can increase creatinine levels by increasing muscle breakdown $(\underline{16}, \underline{17})$. Jones et al. also reported that the higher $\mathrm{sCr}$ level in men compared with women for each age group might be attributed to the greater muscle mass in men (18). Ghasemi et al. reported that concentrations of $\mathrm{sCr}$ are genderdependent in Iranian children and ranging between 1.20 to $6.0 \mathrm{mg} / \mathrm{dl}$ and 1.00 to 6.0 $\mathrm{mg} / \mathrm{dl}$ in Iranian boys and girls, respectively (19). In a previous study, children had significantly lower $\mathrm{sCr}$ and $\mathrm{BUN}$ values than adults. In our study, $\mathrm{sCr}$ and $\mathrm{BUN}$ values were significantly higher in males than in females, while the concentrations of sCr increased with age. On the contrary, the BCR value decreased with age, which is consistent with a previous report (20). On the contrary, Burritt et al. reported higher BUN levels in children compared with adults (15). Hristova and Henry reported a reference interval of 10-20 for the BCR; although, for most individuals, BCR ranged between 12 and 16.5. High BCR with normal $\mathrm{sCr}$ levels are typically associated with high protein intake. A low BCR could reflect low protein intake in patients with severe liver disease, but this is extremely rare (21). In our study, the maximum reference value of $\mathrm{BCR}$ in children was lower than the maximum reference value in adults. This could be due to a high protein intake in the study population. Another study also stated that higher BUN and $\mathrm{sCr}$ reference values in children may be due to an unusually high protein intake (22). However, geographic and lifestyle factors may also influence these values $(\underline{23}, \underline{24})$. The reference values obtained in our study are similar to those obtained for Spanish children (14).

\section{CONCLUSION}

This study is the first to establish reference 
values for $\mathrm{BUN}, \mathrm{sCr}$ and $\mathrm{BCR}$ among healthy Iranian children. We have defined age-specific reference values to guide the evaluation of kidney function and hydration status in healthy Iranian children. Moreover, these findings can be beneficial for renal disease examination and therapeutic procedures.

\section{ACKNOWLEDGMENTS}

The authors would like to thank the research and education department of AliAsghar Children's Hospital for supporting this study.

\section{DECLARATIONS \\ Funding}

Not applicable.

\section{Ethics approvals and consent to participate}

This study was approved by the Local Ethical Committee of Ali-Asghar Children's Hospital, Tehran, Iran. All personal remained confidential throughout the study.

\section{Conflict of interest}

The authors declare that there is no conflict of interest.

\section{REFERENCES}

1. Jose H. Salazar, MS, MLS (ASCP) CM. Overview of Urea and Creatinine. Laboratory Medicine. 2014; 45: e19-e20. [View at Publisher] [DOI] [Google Scholar]

2. Tietz Textbook of Clinical Chemistry. Fourth edition. Edited by CA Burtis, ER Ashwood, DE Bruns. WB Saunders Company, Philadelphia, 2006; 24:801-803. [Google Scholar]

3. Maroni B Steinman T Mitch W. A method for estimating nitrogen intake of patients with chronic renal failure. Kidney Int. 1985; 27:58-65. [View at Publisher] [DOI] [PubMed] [Google Scholar]

4. Fawcett J Scott E. A rapid and precise method for the determination of urea. J Clin
Path. 1960:13:156. [View at Publisher] [DOI] [PubMed] [Google Scholar]

5. Laterza O Price C Scott M. Cystatin C: an improved estimator of glomerular filtration rate? .Clin Chem. 2002:48:699707. [View at Publisher] [DOI] [PubMed] [Google Scholar]

6. Edelstein, C.L. Biomarkers of acute kidney injury. Adv Chronic Kidney Dis. 2008; 15:222-234. [View at Publisher] [DOI] [PubMed] [Google Scholar]

7. Manoeuvrier G, Bach-Ngohou K, Batard E, Masson D, Trewick D. Diagnostic performance of serum blood urea nitrogen to creatinine ratio for distinguishing prerenal from intrinsic acute kidney injury in the emergency department. BMC Nephrol. 2017; 18:173. [View at Publisher] [DOI] [PubMed] [Google Scholar]

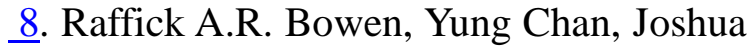
Cohen, Nadja N. Rehak, Glen L. Hortin, Gyorgy Csako, Alan T.Remaley.Effect of Blood Collection Tubes on Total Triiodothyronine and Other Laboratory Assays.Clinical Chemistry. 2005; 51: 424433. [View at Publisher] [DOI] [PubMed] [Google Scholar]

9. Bowen RA, Remaley AT. Interferences from blood collection tube components on clinical chemistry assays. Biochem Med (Zagreb). 2014;24:31-44. [View at Publisher] [DOI] [PubMed] [Google Scholar]

10. Ohmann S.Quality control for clinical chemistry laboratory. Qual Assur. 1997; 5:79-93. [View at Publisher] [PubMed] [Google Scholar]

11. Horn PS, Pesce AJ.Reference intervals: An update. Clin Chim Acta. 2003; 334: 523. [View at Publisher] [DOI] [PubMed] [Google Scholar]

12. National Committee for Clinical Laboratory Standards. How to define, 
determine, and utilize reference intervals in the clinical laboratory; approved guidelinesecond edition C28-A2, volume 20, no. 13. Wayne, PA: NCCLS; 2000.

13. Jagarinec N, Flegar-Mestric Z, Surina B, Vrhovski-Hebrang D, Preden-Kerekovic V. Pediatric reference intervals for 34 biochemical analytes in urban school children and adolescents. Clin Chem Lab Med. 1998; 36:327-37. [View at Publisher] [DOI] [PubMed] [Google Scholar]

14. Gomez P, Coca C, Vargas C, Acebillo J, Martinez A. Normal reference-intervals for 20 biochemical variables in healthy infants, children, and adolescents. Clin Chem. 1984; 30:407-412. [View at Publisher] [DOI] [PubMed] [Google Scholar]

15. Burritt MF, Slockbower JM, Forsman RW, Offord KP, Bergstralh EJ, Smithson WA. Pediatric reference intervals for 19 biologic variables in healthy children. Mayo Clinic Proceedings. 1990; 65:329-36. [View at Publisher] [DOI] [PubMed] [Google Scholar]

16. Bjornsson TD. Use of serum creatinine to determine renal function. Clin Pharmacokinet. 1979; 4:200-2. [View at Publisher] [DOI] [PubMed] [Google Scholar]

17. Perrone RD, Madias NE, Levey AS. Serum creatinine as an index of renal function: new insights into old concepts. Clin Chem. 1992; 38:1933-53. [View at Publisher] [DOI] [PubMed] [Google Scholar]

18. Jones CA1, McQuillan GM, Kusek JW, Eberhardt MS, Herman WH, Coresh J, Salive M, Jones CP, Agodoa LY. Serum creatinine levels in the US population: Third National Health and Nutrition Examination Survey. Am J Kidney Dis. 1998; 32: 992-9. [View at Publisher] [DOI] [PubMed] [Google Scholar]

How to Cite: Rahbar M, Mardanpour K, Mardanpour N. Blood Urea Nitrogen, Serum Creatinine and Blood Urea Nitrogen to Creatinine Ratio Reference Values in Iranian Children. Journal of Clinical and Basic Research. 2021; 5 (1) :14-21
19. Ghasemi, Asghar; Azimzadeh, Iraj; Afghan, Marjan; Momenan, Amir Abbas; Bagheripour, Fatemeh; Azizi, Fereidoun.Pediatric Reference Values for Serum Creatinine and Estimated Glomerular Filtration Rate in Iranians: Tehran Lipid and Glucose Study.AIM. 2015; 18: 753-759. [View at Publisher] [PubMed] [Google Scholar]

20. Dong-Shang Lai, Shivan-Chih Chen, Yih-Hsin Chang, Chien-Yi Chen, Jye-Bin Lin, Yi-Jiun Lin1, Shun-Fa Yang, ChiChiang Yang, Wen-Kang Chen, Ding-Bang Lin. Pediatric reference intervals for several biochemical analyses in school children in Central Taiwan. J Formos Med Assoc. 2009; 108:957-63. [View at Publisher] [DOI] [PubMed] [Google Scholar]

21. Hristova, EN, Henry, JB. Metabolic intermediates, inorganic ions, and biochemical markers of bone metabolism. In: JB Henry (Ed.) Clinical Diagnosis and Management by Laboratory Methods. 12th edition. WB Saunders, Philadelphia; 2001:180-210. [View at Publisher] [Google Scholar]

22. Nanji AA, Blank D. The serum urea nitrogen/creatinine ratio and liver disease. Clin Chem. 1982; 28:1398-9. [View at Publisher] [DOI] [PubMed] [Google Scholar]

23. Ghoshal AK, Soldin SJ. Evaluation of the Dade Behring Dimension RxL: integrated chemistry system-pediatric reference ranges. Clin Chim Acta 2003; 331:135-46. [View at Publisher] [DOI] [PubMed] [Google Scholar]

24. Brinkworth RSA, Witham E, Nazeran H. Establishment of pediatric biochemical reference intervals. Ann Clin Biochem. 2004; 41:321-9. [View at Publisher] [DOI] [PubMed] [Google Scholar] 